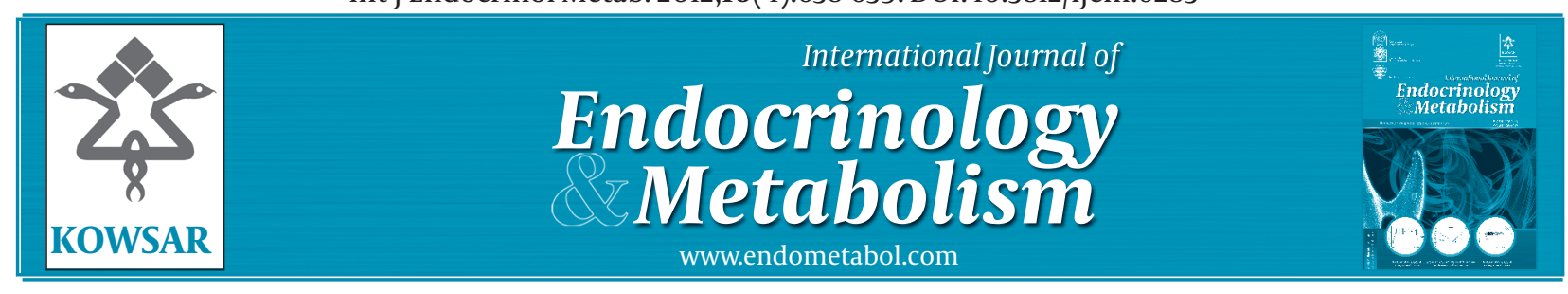

\title{
Safety of Raloxifene in Hemodialysis Patients
}

\author{
Didy Jacobsen ${ }^{1^{*}}$ \\ ${ }^{1}$ Geriatric Department, Radboud University Medical Center, Nijmegen, The Netherlands
}

\section{A R T I C L E I N F O}

\section{Article type:}

Letter to Editor

Article history:

Received: 09 May 2012

Revised: 09 May 2012

Accepted: 12 May 2012

\section{Keywords:}

Raloxifene

Hemodialysis

\section{Dear Editor,}

With interest I read the article from Saito and colleagues about "the effects of raloxifene on bone metabolism in hemodialysis patients with type 2 diabetes" (1). The article addresses the possibility of treatment with raloxifene for osteoporosis in these patients. Raloxifene, a selective estrogen receptor modulator could be a good option, because it has no known renal side effects like bisphosphonates. Additionally, bisphosphonate use in chronic kidney disease is associated with adynamic bone disease, compared with a low bone turnover (2). In another trial in a group of 17 postmenopausal hemodialysis patients raloxifene improved lumbar spine Bone Mineral Density (BMD) by $2.6 \%$ in $53 \%$ of the patients while $70 \%$ of the control group consisting of 10 aged-matched women showed a reduction in BMD by $4 \%$. The effects of raloxifene on serum calcium and serum iPTH level suggest it improves bone resorption (3). Primary, in these patients treatment of secondary hyperparathyroidism should be performed as is recommended (4). However of concern is the safety of raloxifene treatment in this patient group with multimorbidity. Long term studies should be per-

\section{Please cite this paper as:}

Jacobsen D. Safety of Raloxifene in Hemodialysis Patients. Int J Endocrinol Metab. 2012;10(4):638-9. DOI: 10.5812/ijem.6285

Published by Kowsar Corp, 2012. cc 3.0.

formed to determine the efficacy and safety of raloxifene in hemodialysis patients.

Diabetes mellitus and chronic kidney disease both have a negative effect on bone metabolism and there is an increased risk of vascular complications. In the dialysis population the incidence of myocardial infarction and stroke is 5- to 15 fold higher (5) and cardiovascular mortality is 10- to 30 -fold higher (6) than seen in the general population (7-9).

In this hemodialysis population with or without diabetes mellitus I would expect an increased risk of fatal stroke with raloxifene therapy. Taking into account the data of the RUTH-trial in 10101 postmenopausal women with a mean age of 67 years, with a high Framingham Stroke Risk Score (FSRS) ( $\geq 13$ ), a 75\% increased risk of raloxifene -associated fatal stroke was found. (HR 1.75; 95\% CI, 1.01-3.02) (10). The FSRS includes the classical risk factors for cardiovascular disease including age, sex, systolic blood pressure, total and high density lipoprotein cholesterol, diabetes mellitus, smoking and echocardiogram based left ventricular hypertrophy (11-13). This score was originally validated for people aged up to 75 years (14). The FSRS also seems to underestimate the vascular risk

\footnotetext{
* Corresponding author: Didy Jacobsen, Geriatric Department, Radboud University Medical Center, Nijmegen, The Netherlands. Tel:+31-243616772 , Fax: +31243617408,E-mail: d.jacobsen@ger.umcn.nl

DOI:10.5812/ijem.6285

(c) 2012 Research Institute For Endocrine Sciences and Iran Endocrine Society; Published by Kowsar Corp.

This is an open access article distributed under the terms of the Creative Commons Attribution License (http://creativecommons.org/licenses/by/3.0), which permits unrestricted use, distribution, and reproduction in any medium, provided the original work is properly cited.
} 
in hemodialysis patients. The prevalence of traditional cardiovascular disease risk factors is very high in this hemodialysisgroup, but seems not to explain all of the increased cardiovascular risk (15).

I would recommend a longer term randomized, doubleblind, placebo-controlled trial in hemodialysis patients (subgroup analysis with or without diabetes mellitus). Raloxifene versus placebo should be given for 3 years with attention to the change in BMD and monitoring fractures and vascular complications. First it should be shown that the number needed to treat to prevent fracture is clearly smaller than the number needed to harm in a clinical trial of the duration of the required raloxifene treatment before raloxifene can be safely recommended as common practice in the treatment of osteoporosis in hemodialysis patients. Saito et al. performed an important preliminary study that warrants the investment of such a trial to reach the quality standard of safe and evidence based therapy in this vulnerable patient group.

\section{Financial Disclosure}

None declared.

\section{References}

1. Saito O, Saito T, Asakura S, Akimoto T, Inoue M, Ando Y, et al. Effects of Raloxifene on Bone Metabolism in Hemodialysis Patients With Type 2 Diabetes. Int J Endocrinol Metab. 2012;10 (2):464-9.

2. Amerling R, Harbord NB, Pullman J, Feinfeld DA. Bisphosphonate use in chronic kidney disease: association with adynamic bone disease in a bone histology series. Blood Purif. 2010;29 (3):293-9.

3. Tanaka M, Itoh K, Matsushita K, Moriishi M, Kawanishi H, Fukagawa M. Effects of raloxifene on bone mineral metabolism in post- menopausal Japanese women on hemodialysis. Ther Apher Dial. 2011;15 Suppl 1:62-6.

4. Uhlig K, Berns JS, Kestenbaum B, Kumar R, Leonard MB, Martin $\mathrm{KJ}$, et al. KDOQI US commentary on the 2009 KDIGO clinical practice guideline for the diagnosis, evaluation, and treatment of CKD-mineral and bone disorder (CKD-MBD). Am J Kid Dis. 2010;55 (5):773-99.

5. Parfrey PS, Foley RN, Harnett JD, Kent GM, Murray D, Barre PE. Outcome and risk factors of ischemic heart disease in chronic uremia. Kidney Int. 1996;49 (5):1428-34.

6. Sarnak MJ, Levey AS. Cardiovascular disease and chronic renal disease: a new paradigm. Am J Kidney Dis. 2000;35 (4 Suppl 1):S11731.

7. Churchill DN, Taylor DW, Cook RJ, LaPlante P, Barre P, Cartier P, et al. Canadian Hemodialysis Morbidity Study. Am J Kidney Dis. 1992;19 (3):214-34

8. Lindner A, Charra B, Sherrard DJ, Scribner BH. Accelerated atherosclerosis in prolonged maintenance hemodialysis. $N$ Engl J Med.1974;290 (13):697-701.

9. Rostand SG, Kirk KA, Rutsky EA. Relationship of coronary risk factors to hemodialysis-associated ischemic heart disease. Kidney Int. 1982;22 (3):304-8.

10. Barrett-Connor E, Cox DA, Song J, Mitlak B, Mosca L, Grady D. Raloxifene and risk for stroke based on the framingham stroke risk score. Am J Med. 2009;122 (8):754-61.

11. Kagan A, Dawber TR, Kannel WB, Revotskie N. The Framingham study: a prospective study of coronary heart disease. Fed Proc. 1962;21 (4)Pt 2:52-7.

12. Kannel WB. Coronary heart disease risk factors in the elderly. Am J Geriatr Cardiol. 2002;11 (2):101-7.

13. Kannel WB, Dawber TR, Kagan A, Revotskie N, Stokes J. Factors of risk in the development of coronary heart disease-six year follow-up experience. The Framingham Study. Ann Intern Med. 1961;55:33-50.

14. Anderson KM, Wilson PW, Odell PM, Kannel WB. An updated coronary risk profile. A statement for health professionals. Circulation. 1991;83 (1):356-62.

15. Longenecker JC, Coresh J, Powe NR, Levey AS, Fink NE, Martin A, et al. Traditional cardiovascular disease risk factors in dialysis patients compared with the general population: the CHOICE Study. J Am Soc Nephrol. 2002;13 (7):1918-27. 